\title{
A PRAGMATIC STUDY OF HEDGES IN AMERICAN POLITICAL EDITORIALS
}

\author{
*Ali Sabah Hassan, **Asst. Prof Nadya Khairy Muhamed Said \\ *Dept. of English / College of Education for Human Sciences/IbnRushd/ University of Baghdad/ Baghdad, Iraq \\ **Dept. of English / College of Education for Human Sciences/ IbnRushd/ University of Baghdad/ Baghdad, Iraq
}

DOI: $10.37648 /$ ijrssh.v10i03.007

Received:28 ${ }^{\text {th }}$ May, 2020; Accepted:07 $7^{\text {th }}$ June, 2020; Published: $30^{\text {th }}$ June,2020

\begin{abstract}
The use of hedges in newspaper editorialsis important as the claims of editorialists should be cautious when criticizing issues and tackling controversial subject matters. Furthermore, hedges play an essential role where they may affect how readers approvethe truth of the information presented in editorials. This study is aimedto identify the pragmatic functions of hedges and their formal realizations in the American political editorials.Twenty-five editorials, randomly selectedfrom the American online newspapers, and they were analyzedin accordance with a proposed model which is based on the works of the researchers; Hyland (1998), Neff van Aertsalaer and Bunce (2011) and Malášková (2014). The study has concluded that the use of hedges in the American political editorials achieves three hedging functions subsumed under the categories; a) content-oriented hedges, b) writer-oriented hedges, and c) reader-oriented hedges, and the category ofcontent-oriented hedges is the most frequent functional category. These functions can be summed up that using hedges allows the writer not only to invest a certain degree of commitment into the truth value of the proposition, but also to establish and maintain contact with the readers. In additions, single-lexical hedging forms, specifically 'epistemic modal verb' and 'epistemic adverb' are the most frequent formal realizations of content-oriented hedges, whilethe majority ofwriter oriented hedges is dominantly realized by non-lexical hedging forms and the strategy of 'attribution to literature' of its two basic types verbaland verblessbeing the most frequent ones.And as for reader-oriented function,the non-lexical hedging forms, particularly the strategies of 'questions' and 'if clause' are the most frequent formal realizations to fulfill this function.
\end{abstract}

Keywords:Political editorials, hedges,pragmatic functions, formal realizations, newspaper discourse

\section{INTRODUCTION}

The concept of hedges is considered as one of the crucial characteristics of language which severs human communication as makes it more flexible, moderate and convincing. Hedges are with polyfunctional aspects. They convey 'intentional vagueness', 'mitigation', 'tentativeness', 'politeness', 'indirectness', 'possibility', 'evasiveness', 'lack of full commitment', and showing deference to the readers as opinions are kept opened of other interpretations. As language means, hedges can be characterized as they express the attitude of the writer towards both the propositional information and his/her awareness to the readers. As hedging in academic genres has received a great investigation being a major feature of linguistic behavior in such genres, this study tends to 
examine hedges in journalisticlanguage, specifically in editorials, such a kind of discourse where hedges are employed heavily. It is worthy to consider newspapers editorials as a genre of analyzing hedges where these types of articles according to Tahririan\&Shahzamani (2009), "represent the position of a newspaper on particular national concerns and underline the reputation of a newspaper".

They (ibid.) assume that the use of hedges in editorials is to "reduce potential risk of a claim or prevent embarrassing situations in case one is found to be wrong". Editorialists may jeopardize the reputation of a newspaper if their claims are not cautious, specifically when criticizing issues and tackling controversial subject matters.They soften their claims in discussing such topics whenthey are not confident in validating their assertions with facts that the readers consider acceptable. Thus, the use of hedges is therefore important in editorials. Furthermore, hedges play an essential role where they may affect how readers approve the claims of editorialists. This study aims to identify the pragmatic functions of hedges and their formal realizations in the American political editorials.

\section{LITERATURE REVIEW}

\subsection{Hedges: Definitions}

In dictionaries of linguistics, the terms hedge, hedging are not prevalent very often. However, a Dictionary of Stylistics categorizes hedging in the light of the fields of 'discourse analysis', 'politeness' and 'speech act theory' and defines itas "qualification and toning-down of utterances and statements in speech and writing, by modality, adverbials, etc., in order to reduce the riskiness of what one says". As for hedges, they are referred in the narrower sense (based on Lakoff) as semantic modifiers which qualify prototypes (Wales, 2011:197).

Linguists provided a number of definitions concerning this phenomenon (hedges). The first linguist who introduced the term hedges to the linguistic literature was Lakoff who defined it as "words whose meaning implicitly involves fuzziness, words whose job is to make things fuzzy or less fuzzy" (Lakoff, 1973: 471). According to Nikula (1997: 188), hedges are linguistic devices by which speakers lessen the force of what they state to make their utterances more acceptable to the hearers.

Schröder and Zimmer (1997:249) draw a distinction between the terms hedge and hedging. They define the term hedge as "one or more lexico-syntactical elements that are used to modify a proposition". Whereas hedging, it is the act or strategy of employing linguistic devices as hedges in specific context for certain communicative goals,such as vagueness, mitigation, politeness, etc. Thus, hedges are deemed to be as realization means of an 'interactional strategy' which is labeled as hedging.

To Hyland (1998:1), hedges are defined as the linguistic devices that are employed to point out either a lack of full adherence as to the truth value of propositions or a wish to not convey that commitment in absolute way.In addition, Hyland (2005: 99) reports that hedges are crucial means for expecting a reader potential refusal of a proposition. They allow to express the attitude of the writer towards the truth of a statement and to present claims with accuracy, prudence and showing deference as to the views of the audience. Salager- Meyer (1994:150) associates hedges with 'intentional vagueness' and with 'tentativeness', to maximize the acceptance of sentences to recipients and to decrease their disapproval.

Rounds (as cited in Salager-Meyer,1994:151) debates that hedges can be used to reach an agreement concerning the information under investigation, that is, to reach to a wider accuracy concerning the claims presented. According to Malášková (2014:33), hedges are essential language tools by which writers interact with the readers in the text, since hedges help to open space to discuss and evaluate issues in the text.

\subsection{Hedges: A Concise History of the Concept}

Markkanen \& Schröder (1997:4) state that Lakoff was the first linguist to present the term hedges in the linguistic literature in his article 'Hedges: A Study in Meaning Criteria and the Logic of Fuzzy Concepts' (1973). He was not concerned with the use of hedges in that they have communicative significance, but he was more interested with the semantic and logical 
characteristics of words and phrases such as rather, sort of and their task to make things less fuzzy or fuzzier.

The concept of hedges shifted from the semantic perspective to the pragmatic one. Fraser (1975) shows that hedges may have an interaction with'performative verbs' which are elaborated and termed by him as 'hedged performatives'. Fraser (ibid.) explained that when specific 'performative verbs' like apologize, promise, request, preceded by certain modals such as can, must, should, the consequence would be a mitigation in the illocutionary force of the speech act denoted by the verb, without labeling the modals as hedges. For example:

\section{(1) I should apologize for running over yourcat.}

Brown and Levinson (1987:171-172) studied the way hedges lessen the force of speech acts to minimize speaker's or writer's responsibility towards a proposition in general .Thus, this kind of hedging is called 'speech act hedging'.Prince et al. (1980) made an important contribution by investigating hedging in spoken medical discourse.They (ibid: 7-8) classified hedges into two kinds. The first one is 'approximators', these are hedges which make some modification on the propositional content of the utterance 'propositional hedging'.The second one is'shields', these are hedges which demonstrate the speaker's responsibility towards the truth of the entire proposition and do not have an effect on the propositional content, but the speaker implies degrees of doubt to a proposition 'speech act hedging'. The category of approximators' is subdivided into 'adaptors' and 'rounders'. The former subcategory is hedges that relate to class membership. They make a modification of a term to fit a 'non-prototypical situation' (e.g. sort of, somewhat, a little bit, etc.). For example:

\section{(2) She noticed that he was a little bit blue.}

The latter subcategory is hedges which show that a term is not completely accurate. They try to measure things or limit their range (e.g. range about, approximately, something around, etc). For example:

(3)His weight was approximately 3.2 kilograms.
They (ibid:11-12) show that as regards to the second type 'shields', it is subdivided into'plausibility shields'and'attribution shields'.The former subcategory is hedges which are linked to doubt or uncertainty (e.g. I think, probably, as far as I can tell, etc.). For instance:

(4) I thinkwe can just slow him down to a little over maintenance.

The statements indicated by 'plausibility shields' implicate that an assertion is made by the speaker based on reasonable grounds. The latter subcategory includes expressions such as (according to her estimates, presumably, etc.) which ascribe the commitment to someone else than the speaker or the writer. For example:

(5)He was not very ill, according to her estimate.(ibid.).

Hübler (1983) contributes to the phenomenon of hedges by making a distinction between understatements and hedges. He differentiates between two types of indeterminations 'phrastic' and 'neustic'. The indetermination of the 'phrastic' affects the propositional content of the utterance,and this is called understatement. For example:

(6)It's a bit cold in here.

Concerning hedges, these are limited by the indetermination of the 'neustic', which means they indicate the attitude of the speaker to the hearer concerning the proposition conveyed. For example:

(7)It is cold in Alaska, I suppose. (ibid.).

Finally, Caffi (2007:98- 99) suggested a categorization of three mitigating devices (bushes, hedges and shields). 'Bushes' are lexical terms that are concerned with diminishing the accuracy of a predicate in the utterance and that may convey vagueness, thus softening the commitment to the propositional content. 'Hedges' are lexical expressions that mitigate the illocutionary force of the speech act. Thereby, the commitment of speaker is qualified towards the truth of the proposition expressed. The last category of 'shields',these are devices used to express an avoidance of ascribing the utterance to the speaker in that the commitment is attributed to someone else than the speaker. 


\subsection{Communicative Functions of Hedges}

Falahati (as cited in Laurinaityte, 2011:12) shows that there are two essential approaches towards the functions of hedges: hedges in politeness model and hedges in polypragmatic model.

\subsubsection{Hedges in Politeness Model}

The use of hedges according to politeness theory can be viewed as a strategy of both kinds of politeness, as follows:

\subsubsection{The Use of Hedges as a Negative Politeness Strategy}

According to Holmes (1995:77), hedges are regarded as devices to achieve negative politeness, for they convey deference to people of diverse social class as well as to mitigate the strength of face-threatening acts. For example:

\section{(8)I wonder if you could help me with lifting this box.}

The use of hedging expression in the example above is motivated by the speaker in order to not to force unwelcome request to the hearer and also by the willingness to protect the face of either the speaker's or the hearer's.

Salager- Meyer (1994: 150) in her investigation of hedges in medical discourse, demonstrates that hedges are motivated to qualify the information conveyed, so, on the one hand, authors signify negative politeness to the audience through leaving a space for the opinions of readership to be expressed, thus avoiding to impose their thoughts and to protect the negative face of the audience. On the other hand, hedges are treated as a strategy of 'self-protection' that can be used for saving the author's negative face. In being uncertain and avoiding to be assertive, through the use of hedging devices, the author can be non-committal concerning the information conveyed, to evade from the criticism of audience. For example:

(9)We assume that the input species [of computer viruses] are all related: that the tripartite graph joining characters to species...
The use of hedging expression in the example above indicates negative politeness. The author states his/her own view in the research on computer viruses and he/she takes into consideration the respective audience's own opinion about the nature of computer viruses, for protecting the negative face of the audience ,and himself /herself from any possible criticism.

\subsubsection{The Use of Hedges as a Positive Politeness Strategy}

Whereas the use of hedges has been deemed as a strategy of negative politeness, it may also be viewed as a strategy that has an indication to positive politeness. Though such characteristic has received a little investigation, it nevertheless discussed by some scholars like Aijmer (1986: 15) who declares that "the focus in the communication situation is on the relationship between speaker and hearer, the hedge can therefore become a strategy signaling intimacy and rapport".

According to Brown and Levinson (1987: 101), one way to indicate positive politeness is the fact to convey "that one's own wants (or some of them ) are in some respects similar to the addressee's wants", to avert the conflict and searching for agreement. This strategy of avoidance implies that the speaker makes his view 'safely vague' to seek agreement with the addressee, as in the following example:

(10)In a way, that painting is beautiful.

Employing such a hedge in the example above shows that the speaker evades to convey his view in a precise way and seeks the hearer "to use his common knowledge" when understanding the opinion of the speaker. It can be also realized to protect the positive face of the sender indicating that the sender seeks for agreement by not making a categorical statement which is debatable regarding the respective issue. By introducing a view in a way that may be assumed "to invite the addressee to acknowledge the sender's proposal that at least some features of the painting are beautiful", the sender may then protect his positive face. Concerning the second approach towards the function of hedges is the polypragmatic model proposed by Hyland (1998). The following section and subsections discuss the model meticulously. 


\subsubsection{Hedges in Polypragmatic Model}

Hyland (1998) divides hedges into two main categories: content-oriented hedges and reader-oriented ones.Hyland, by proposing this model, tries to capture the multi-functional nature of hedges as in the figure below:

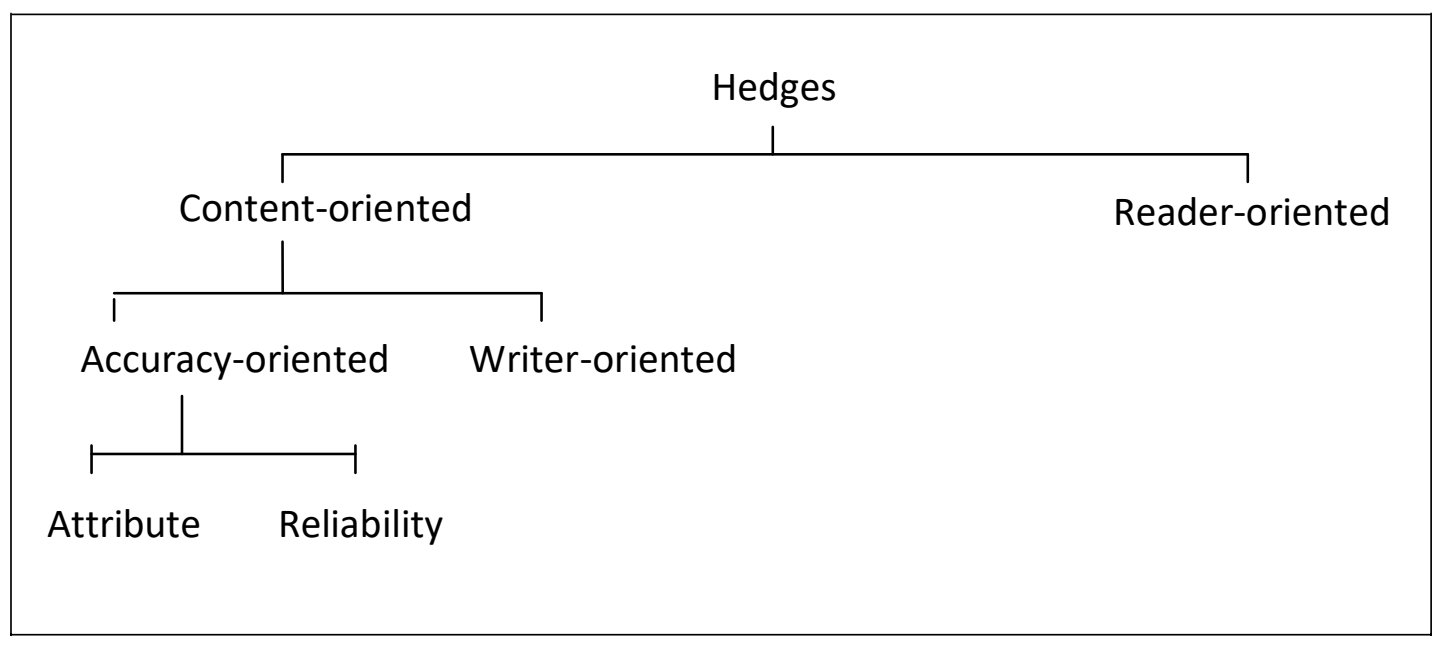

Figure (1): Hyland's model of hedging (1998)

The following subsections are an endeavor to classify thepragmatic functions of hedges according to this model.

\subsubsection{Content-Oriented Hedges}

Hyland (1998:162) states that the motives of using content- oriented hedges is of twofold-it pertains the interest of the writer to state the propositional information with reality, and the need for 'selfprotection' from unfavorable repercussions from the side of the audience.In accordance with these motivations, Hyland (ibid.) distinguishes between two kinds of content-oriented hedges: accuracy-oriented hedges and writer-oriented hedges.

The essential function of accuracy-oriented hedges is to signify that "the proposition is based on plausible reasoning in the absence of certain knowledge". These hedges request the reader to interpret what is stated as true as far as can be determined. Two kinds of accuracy-oriented hedges are distinguished by Hyland: attribute hedges and reliability hedges(ibid).

Attribute hedges are involved with the precision of the propositional content. They mark varying degree of precision by indicating "the extent to which the information in the proposition is true or applicable to real life phenomena". These functions are realized by degree of precision adverbs. These include downtoners and style disjuncts.For example:

(11)Linkage analysis to affective illness with 310 DNA markers (covering about 50\% of the genome).

The existence of downtoner (approximator) about is an indication of "the degree of precision intended and to convey the sense in which an idea may be held to be true" (ibid: 163).

As for reliability hedges, they markthe subjective assessment of the writer of the potential of "the propositional information being or becoming true". These hedges are realized by epistemic modal verbs, epistemic adjectives, epistemic nouns and adverbs, content disjuncts, and limited knowledge. For example: 
(12) Another possibility is related to the personality traits of many women entrepreneurs.

The epistemic noun (hedge) possibility marks the explanation proffered in such a way to specify that what is stated is not absolutely correct proven, but is a deduction on the "basis of the evidence available" (Hyland, 1998:166).

\subsubsection{Writer-Oriented Hedges}

Hyland (1998: 170) explains that this functional kind of hedges acts with the writer's intention to withdraw his/her complete commitment of the claim he/she delivers and the responsibility is switched to sources outside the writer to shield himself/herself from unfavorable reactions. Sentences with such hedges involve using 'impersonal subjects' like (abstract rhetors and clausal subjects) in combination with epistemic lexical verbs (14).Other forms include epistemic lexical verbs in the passive form (13). These formal realizations often occur together to fulfill the writer-oriented function. For example

(13)It is argued here that students should learn DMs..

(14) The research here also suggests a need to return to meaning in non- native discourse.

\subsubsection{Reader-Oriented Hedges}

The last functional category is deemed to be an interpersonal strategy, where the concern is the interaction between the writer and the reader. By using such hedges, the writer intends to drag the reader into the text, indicating that the readers' viewpoints are taken into consideration and to convey the idea that the readers share in developing the discussion. Readeroriented hedges are depicted as the writer expresses his/her awareness to the audience (Hyland,1998:172).The formal realizations of readeroriented hedges are done through typical means such as personal attribution, i.e. clauses with personal pronouns as subjects with epistemic verbs. For instance:

(15)I believe I have brought enough evidence to support the standpoint.
Hypothetical conditionalsare among the formal realizations that work as reader-oriented hedges which involve ways of suggesting, where the offered claim is presented as one possibility of many. For example:

(16)If we assume that the apparent molecular weight obtained by SDS PAGE is correct, this suggests that only a few amino acids are missing..(ibid:183).

Questions canbe used as reader- oriented hedgesto indicate "tentativeness of a solution" and appealing to the readers in that they are engaged in drawing conclusions .For example:

(17)How is it, then, that this gene from a species that never forms nodules has the capacity to be expressed at elevated levels nodules?(ibid.).

\subsection{Taxonomy of Hedges}

Most of linguists stress that a thorough list of hedges is not provided yet .However, the previous studies of Hyland (1998), Varttala (2001), Neff van Aertselaer and Bunce (2011) and Malášková (2014), provide categories of items which consider as hedges that include lexical and non-lexical means. Their categorizations are not exhaustively different but rather complementing each other.

\subsubsection{Lexical Means of Hedging}

Four essential categories were identified among lexical means of hedging that include verbs (both modal and lexical), adjectives, nouns and adverbs.

\section{Modal Auxiliary Verbs}

Biber et al., (1999:492) state there exist nine main modal auxiliary verbs that are assumed to convey an epistemic meaning which is related to the use of hedging; can, could, may, might, will, would, shall, should, and must.

\section{Epistemic Lexical Verbs}

Hyland (1998:119) distinguishes between two types of epistemic lexical verbs: epistemic judgment verbs and epistemic evidential verbs. The former category involves speculative verbs (e.g. assume, predict, 
propose, believe) and deductive verbs(e.g. calculate, infer, conclude, deduce). Both are used to convey what is being stated is tentative and based on the writer's judgment. The latter category includes quotative verbs (e.g. report, note) and sensory verbs(e.g. seem, appear) which are concerned with "nature of evidence the writer employs to support a claim".

\section{Epistemic Adjectives}

According to Varttala (2001) and Malášková (2014), four subtypes of adjectives that can operate as hedges:probability adjectives(e.g. probable, un/likely, possible), adjectives of indefinite degree(e.g. significant, considerable, slight), adjectives of indefinite frequency(e.g. common, normal, general, typical)andapproximative adjectives(e.g. approximate, close, virtual, about, round).

\section{Epistemic Nouns}

It seems that there are a set of nouns with epistemic sense that can achieve hedging aims. Varttala (2001:139) divides nouns that work as hedges into: non-factive assertive nouns(e.g. allegation, prediction, proposal, suggestion, indication,implication), tentative cognition nouns(e.g. assumption, belief, estimation, guess, hypothesis, supposition)and tentative likelihood nouns(e.g. likelihood, possibility, prospect, tendency).

\section{Epistemic Adverbs}

Varttala (2001) and Malášková (2014) categorize adverbs that function as hedges into: adverbs of indefinite degree(e.g. somewhat, fairly, rather, slightly), adverbs of indefinite frequency(e.g. seldom, not always, rarely, sometimes, generally,often), adverbs of doubt /certainty(e.g. potentially, presumably, perhaps, likely), adverbs of approximation(e.g. almost, about, roughly, around, nearly)and adverbs of evidence(e.g. apparently, evidently, obviously, admittedly, reportedly, allegedly).

\section{Other}

Indefinite quantifiers are subsumed under this category as Hinkel (2004:319) shows that indefinite quantifiers can work as hedges such as (a lot of, a bit of, some, a number of, a little).

\subsubsection{Non-lexical Means of Hedging}

There is a broader range of clausal and phrasal constructions that function as hedges.

\section{Personal Attribution}

Hyland (1998:182) declares that personal commitment might qualify the expression of a proposition and is deemed to be as subjective view, taking into account other views from the side of the audience. For example:

(18)We believe that an interpretation of metaphor..

\section{Abstract Rhetors}

Abstract rhetors according to Malášková (2014:133), are abstract nouns which refer "to different parts of the source text" like (problem, similarity, study, extract, report, summit, discussion), and mostly appear with epistemic lexical verbsto function as a writer-oriented strategy, where such nouns become the source of the claim. For example:

(19)The present study suggestsa core functional paradigm...

\section{General and Unnamed Rhetors}

General and unnamed rhetors refer to non-specific, unnamed human agents that encompass nouns such as (some, many, researchers, analysts, experts) where mostly come with epistemic lexical verbsto work as a writer-oriented strategy(Neff van Aertselaer and Bunce ,2011).For example:

\section{(20) Some people may think that}

\section{Attribution to Literature}

Hyland (1998:174) shows that referring to "a wider body of knowledge in the literature" helps to switch the responsibility as to the truth of statements to outside sources, so as to shield the writer from undesirable comments. For example:

(21)According to Gregory, one of the most frequently employed methods of inducing magnetic sleep... 


\section{Conditional Clauses}

Hyland (1998:146) shows that by employing (ifclauses) "the condition is open and the truth of the proposition is unresolved, thereby hedging the accuracy of the theoretical or descriptive claims". For example:

(22) In unplanned speech, coherence or continuity in utterances may break down if the speaker has covert or unsignalled topic shifts..

\section{Reference to Limited Knowledge}

According to Hyland (1998: 142), acknowledgment to the shortage of knowledge is one possible way in "adjusting the reader's expectations of exactitude as a context for the writer's view on the matter". For example:

(23) Activation might use the underlying network, but it is not at all clear exactly how this activation would work or ....

\section{Questions}

Hyland (1998:183) considers interrogative constructions can convey important unresolved issues, tentativeness when presenting results, and they appeal the readers' response as their turn is considered in the process of appraisal. For example:

(24)And what happens when they enter a community where contestivebehaviour is integral to the linguistic repertoire?

\section{Other}

Under this category, a set of different sorts of sentences and clausal elements that are subsumed to perform hedging functions, yet that cannot be inserted within that other categories. For example:

(25)Given this, one possible answer might lie in reciprocity of correspondence as a kind of administrative politesse. (Malášková ,2014:110-111).

\subsection{Editorials:An Overview}

Editorials are newspaper articles that are commonly institutional not personal. It means that even they are written by a single editor, though editorials are signed rarely, they express the official opinion of a newspaper. This indicates that they are participated by many editorialists or between editorialists and the management. Editorials play a plain role in the shifting and determining of public opinion (Van Dijk ,1996).

Le (2004:688) states that editorials do not only inform, persuade, criticize and praise, but they also prompt debate and dialogue. They are the participation of a newspaper in its community. Editorials, as a communicative genre, are deemed to include three participants: (the editorialists), (the audience), and (the people connected to the case being investigated). Editorialists are members of the argumentation, though this involvement is not indicated by the usage of the first person singular and/or plural, but this is rarely done by them. Editorials take into account the audience to be involved implicitly in the argumentation and some the people connected to issues are referred in explicit ways as sources of information.Editorialists, in order to convey their ideas effectively, resort to employ certain means to convince the readers or altering their attitude towards the subject matter being investigated. Thus, a careful description of editorial's style, structure and employment of lexico-grammatical elements such as interactional metadiscourse markers, where hedges are one of them, play a crucial role to achieve the communicative aim of this persuasive genre (Williams, 2007:65-66).

\section{DATA COLLECTION AND METHODOLOGY}

\subsection{Data Collection}

Newspaper editorials are the adopted data that are going to be analyzed. These editorials are selected from the American newspapers available online, specifically from The Washington Post, The New York Times and USA Today. The corpus amounts to a total of twentyfive editorialsthat were selected randomly and taken from different dates published in 2018 and 2019, with the coverage of most editorials on political issues. These newspapers disseminate daily and they are considered as national and elite newspapers. 


\subsection{Model of Analysis}

For the purpose of analyzing hedges in political editorials, the researcher is going to depend on the revised classification by Malášková's (2014) regarding the hedging functions. She adapts Hyland's classification of hedges(see section 2.3.2) by integrating Hyland's attribute hedges and reliability hedges under one principal category which is content-oriented hedges. The category of writer-oriented hedges is detached from content- oriented hedges to be included under major category participant-oriented hedgeswhich comprises: writer-oriented hedges and reader-oriented hedges. Malášková (2014:50) justifies this detachment as "writer-oriented hedges do not operate within the proposition itself, but the content-oriented ones do". It is believed that the function of writer-oriented hedges is more involved with the strength of the commitment of the writer as to the claim he/she makes, but not with the propositional content .Thus, it seems more appropriate for writer-oriented hedges to be included under thecategory of participant- oriented hedges as it mirrors their function more accurately in the text.

Concerning the formal and strategic means which are employed to express these hedging functions, the researcher is going to include the applicable formal and strategic means. The formal and strategic means that will be incorporated, most of them drawing on the classifications of Hyland (1998), Neff van Aertsalaer and Bunce (2011)and Malášková (2014), (see section 2.4).The proposed model of analysis in this study is illustrated as in the following table:

\begin{tabular}{|c|c|c|}
\hline \multirow{3}{*}{$\begin{array}{l}\text { Content } \\
\text { orientedhedgesexpressed } \\
\text { by: }\end{array}$} & \multicolumn{2}{|c|}{ Participant -oriented hedges } \\
\hline & $\begin{array}{l}\text { Writer- oriented hedges expressed } \\
\text { by: }\end{array}$ & $\begin{array}{l}\text { Reader -oriented hedges } \\
\text { expressed by: }\end{array}$ \\
\hline & Single lexical means & Single lexical means \\
\hline $\begin{array}{l}\text { Single lexical means } \\
\text { - Epistemic adverbs } \\
\text { - Epistemic modal verbs } \\
\text { - Epistemic nouns } \\
\text { - Epistemic adjectives } \\
\text { - Epistemic lexical verbs } \\
\text { - Other (lexical) } \\
\text { Combinations of lexical } \\
\text { means } \\
\text { double / treble } \\
\text { Non-lexical means } \\
\text { - if-clause } \\
\text { - Limited knowledge } \\
\text { - Other (non-lexical) }\end{array}$ & $\begin{array}{l}\text {-Epistemic adverbs } \\
\text {-Epistemic adjectives } \\
\text {-Epistemic noun } \\
\text {-Epistemic lexical verbs } \\
\text { Combinations of lexical means } \\
\text { double / treble } \\
\text { Non-lexical means } \\
\text { - Attribution to literature (verbal / } \\
\text { verbless) } \\
\text { - Abstract rhetor + lexical verb } \\
\text { - General, unnamed rhetor + modal } \\
\text { verb + epistemic lexical verb } \\
\text { - General, unnamed rhetor }+ \\
\text { epistemic lexical verb } \\
\text { - Passive voice } \\
\text { - Other (non-lexical) }\end{array}$ & $\begin{array}{l}\text {-Epistemic modal verbs } \\
\text { - Epistemic lexical verbs } \\
\text { Combinations of lexical } \\
\text { means } \\
\text { double / treble } \\
\text { Non-lexical means } \\
\text { - Direct questions } \\
\text { - if-clause } \\
\text { - Personal attribution } \\
\text { - Other (non-lexical) }\end{array}$ \\
\hline
\end{tabular}

Table (1): The proposed model of analysis 


\section{RESULTS AND DISCUSSION}

\subsection{Formal Realizations of Content-Oriented Hedges in American Political Editorials}

\begin{tabular}{|l|l|l|}
\hline Hedging form(s) & Frequency & Percentage \\
\hline epistemic adverb & 32 & $29.90 \%$ \\
\hline epistemic modal verb & 34 & $31.78 \%$ \\
\hline other (lexical) & 18 & $16.83 \%$ \\
\hline epistemic adjective & 1 & $0.93 \%$ \\
\hline epistemic noun & 0 & $0 \%$ \\
\hline epistemic lexical verb & 7 & $6.54 \%$ \\
\hline Single lexical means total & $\mathbf{9 2}$ & $\mathbf{8 5 . 9 8} \%$ \\
\hline combination of lexical means - double & 5 & $4.67 \%$ \\
\hline combination of lexical means - treble & 0 & $0 \%$ \\
\hline Combined lexical means total & $\mathbf{5}$ & $\mathbf{4 . 6 7 \%}$ \\
\hline if-clause & 3 & $2.81 \%$ \\
\hline limited knowledge & 6 & $5.61 \%$ \\
\hline other (non-lexical) & 1 & $0.93 \%$ \\
\hline Non-lexical means total & $\mathbf{1 0}$ & $\mathbf{9 . 3 5 \%}$ \\
\hline \multicolumn{1}{|c|}{ Total } & $\mathbf{1 0 7}$ & $\mathbf{1 0 0 \%}$ \\
\hline
\end{tabular}

Table (2): Distribution and percentage of formal and strategic means of content-oriented hedges in American political editorials

According to table (2), single lexical hedging formsthat fulfill content-oriented function are the most frequent formal realizationsin the American political editorials .These hedging forms constitute (92) from the total number (107) and rate (85.98\%). 'Epistemic modal verb' is the dominant hedging form among various subcateogries of single lexical hedging forms. This form of hedges occurs with (34) cases representing (31.78\%). 'Epistemic adverb' is the second dominant form of hedges which is identified with (32) occurrences which read (29.90\%). 'Other (lexical)' occurs with the frequency (18) recording $(16.83 \%)$, then followed by 'epistemic lexical verb' with (7) cases to amount (6.54 $\%$ ) and 'epistemic adjective' with the lowest frequency (1) case representing $(0.93 \%)$. The analysis shows that instances of 'epistemic noun' were not identified as single lexical hedging form in the American political editorials. It represents (Null).
The second most frequent formal realizations which expresscontent-oriented function as shown in the table are non-lexical hedging formswhich constitute (10) from the total number (107) and rate $(9.35 \%)$. The strategy of 'limited knowledge' can be regarded as the most frequent among the subcategories of non-lexical hedging forms with the frequency (6) recording $(5.61 \%)$, followed by 'if-clause' with (3) instances that read $(2.81 \%)$ and the construction of 'other (nonlexical)' which is detected with only (1) instance which represents $(0.93 \%)$.

The least frequent formal realizationswithcontentoriented functionare combined lexical hedging forms. They shape (5) from the total number (107) and record (4.67\%). Combined lexical hedging forms (double) were found with the frequency (5) representing (4.67\%), but no examples were identified of combined lexical hedging means (treble). 


\subsection{Formal Realizations of Writer-Oriented Hedges in American Political Editorials}

\begin{tabular}{|l|l|l|}
\hline Hedging form(s) & Frequency & Percentage \\
\hline epistemic adverb & 3 & $4.41 \%$ \\
\hline epistemic adjective & 1 & $1.47 \%$ \\
\hline epistemic noun & 2 & $2.94 \%$ \\
\hline epistemic lexical verb & 1 & $1.47 \%$ \\
\hline Single lexical means total & $\mathbf{7}$ & $\mathbf{1 0 . 2 9 \%}$ \\
\hline combination of lexical means - double & 1 & $1.47 \%$ \\
\hline combination of lexical means - treble & 0 & $0 \%$ \\
\hline Combined lexical means total & $\mathbf{1}$ & $\mathbf{1 . 4 7} \%$ \\
\hline attribution to literature+lexical verb & 25 & $36.76 \%$ \\
\hline attribution to literature (verbless) & 17 & $25.0 \%$ \\
\hline abstract rhetor + lexical verb & 7 & $10.29 \%$ \\
\hline general and unnamed rhetor + lexical verb & 4 & $5.90 \%$ \\
\hline general and unnamed rhetor + modal verb + lexical verb & 1 & $1.47 \%$ \\
\hline passive voice & 6 & $8.82 \%$ \\
\hline other (non-lexical) & 0 & $0 \%$ \\
\hline Non-lexical means total & $\mathbf{6 0}$ & $\mathbf{8 8 . 2 4} \%$ \\
\hline \multicolumn{1}{|c|}{ Total } & $\mathbf{6 8}$ & $\mathbf{1 0 0 \%}$ \\
\hline
\end{tabular}

Table (3): Distribution and percentage of formal and strategic means of writer-oriented hedges in American political editorials

Table (3) reveals that the most frequent formal realizations with writer-oriented functionin the American political editorialsarenon-lexical hedging forms. They shape (60) from the total number (68) and estimate (88.24\%).Various subcategories of non-lexical hedging forms are employed. 'Attribution to literature+ lexical verb' is the most frequent strategy which constitutes (25) instances recording (36.76\%).The second most dominant strategy is 'attribution to literature (verbless)', found with the frequency (17) representing (25.0\%). This strategy is followed by other strategies like 'abstract rhetor + lexical verb' that forms (7) cases rating (10.29\%), 'passive voice' with (6) cases representing $(8.82 \%)$ and 'general and unnamed rhetor + lexical verb' with (4) cases that record (5.90\%). The strategy of the lowest frequency as non-lexical hedging means is 'general and unnamed rhetor + modal verb + lexical verb'. It was only found with (1) instance which amounts (1.47\%). There were no examples found of the construction of 'other (non-lexical)'. It represents (Null).
Single lexical hedging forms with writer-oriented function are deemed to be the second most frequent formalrealizations as shown in the table in the American political editorials. They constitute (7) from the total number (68) and record (10.29\%). 'Epistemic adverb' is the most frequent form of hedges. It was identified with (3) instances estimating (4.41\%), followed by 'epistemic noun' which occurs with (2) instances representing (2.94\%). 'Epistemic adjective' and 'epistemic lexical verb' have similar frequency with (1) case of each to record $(1.47 \%)$.

The table also shows that combined lexical hedging forms with writer-oriented function are the least frequent formal realizations .They form only (1) example from the total number (68) representing $(1.47 \%)$. Only (1) instance of combined lexical hedging forms (double) was found that reads $(1.47 \%)$, but no examples were identified of combined lexical hedging forms (treble). 


\subsection{Formal Realizations of Reader-Oriented Hedges in American Political Editorials}

\begin{tabular}{|l|l|l|}
\hline Hedging form(s) & Frequency & Percentage \\
\hline epistemic modal verb & 3 & $13.63 \%$ \\
\hline epistemic lexical verb & 0 & $0 \%$ \\
\hline Single lexical means total & $\mathbf{3}$ & $\mathbf{1 3 . 6 3 \%}$ \\
\hline combination of lexical means - double & 0 & $0 \%$ \\
\hline combination of lexical means - treble & 0 & $0 \%$ \\
\hline Combined lexical means total & $\mathbf{0}$ & $\mathbf{0 \%}$ \\
\hline question & 12 & $54.55 \%$ \\
\hline if-clause & 5 & $22.74 \%$ \\
\hline personal attribution & 1 & $4.54 \%$ \\
\hline other (non-lexical) & 1 & $4.54 \%$ \\
\hline Non-lexical means total & $\mathbf{1 9}$ & $\mathbf{8 6 . 3 7 \%}$ \\
\hline \multicolumn{1}{|c|}{ Total } & $\mathbf{2 2}$ & $\mathbf{1 0 0 \%}$ \\
\hline
\end{tabular}

Table (4): Distribution and percentage of formal and strategic means of reader-oriented hedges in American political editorials

From table (4) it can be observed that non-lexical hedging forms with reader- oriented function are the most frequent formal realizations in the American political editorials. They constitute (19) from the aggregatenumber (22) recording $(86.37 \%)$. Different non-lexical hedging forms are used. The strategy of 'question' shows the most predominant strategy with the frequency (12) representing $(54.55 \%)$. The second dominant strategy is 'if-clause'with (5) instances found which record $(22.74 \%)$. The rest of hedging forms, namely, 'personal attribution' and the construction of 'other (non-lexical)' are with similar frequency with (1) case of each representing $(4.54 \%)$ in total percentage. editorials are that of single lexical hedging forms. They only form (3) cases from the total number (22) recording (13.63\%).Among single lexical hedging forms, it is merely 'epistemic modal verb' which occurs with (3) instances that estimate (13.63\%). Besides, no instances were found of the hedging form of 'epistemic lexical verb'.

With respect combined lexical hedging means with reader -oriented function, the table indicates that there were no instances identified as to combined lexical hedging means(double) and (treble) through the analysis. Thus, they represent (Null).

The second most frequent formal realizations with reader -oriented function in the American political

4.4Summary of Hedging Functions in American Political Editorials

\begin{tabular}{|l|l|l|}
\hline Functional type & Frequency & Percentage \\
\hline Content-oriented & 107 & $54.32 \%$ \\
\hline Writer-oriented & 68 & $34.52 \%$ \\
\hline Reader-oriented & 22 & $11.16 \%$ \\
\hline Total & $\mathbf{1 9 7}$ & $\mathbf{1 0 0} \%$ \\
\hline
\end{tabular}

Table (5): The results of hedging functions in American political editorials 
Table (5) displays the results of hedging functions in the American political editorials. As it is seen from the table, the functional category of content -oriented hedgesis the most frequent in the American political editorials .With (107) cases identified, they explicate $(54.32 \%)$ of all hedges detected in the data. The category of writer-oriented hedges is the second most frequent functional kind of hedges in the American political editorials. With the total of (68) instances found through the analysis, this functional kind estimates $(34.52 \%)$ in the corpus. The least frequent type of hedging function in the American political editorials is thereader-oriented category. It constitutes (22) from theaggregate number to represent $(11.16 \%)$.

\section{CONCLUSIONS}

1. The American editorialists in political editorials have three essential orientations towards the content of their propositions, towards themselves, and towards their readers. These orientations provide three principle pragmatic motivations for which hedges are used:

a) The editorialists' desire to present the proposition with appropriate degree of accuracy (credibility).

b) The editorialists' intention to withdraw complete commitment of the claim they present for protecting themselves from any possible criticism.

c)To present the claim as only one of the possible in a humble mode, leaving space for the readership to negotiation of the unresolved issue.

2. The functional category of content-oriented hedges is the most frequent one in the American political editorials. Single lexical hedging means, specifically'epistemic modal verb' and 'epistemic adverb' are the most frequent formal realizations ofthis functional category. It seems that the American editorialists rely on such hedging means proving that they are more concerned with presenting their propositions with appropriate degree of accuracy, that is, to establish (credibility). Moreover, revealing that they are more concerned to remain faithful to their role as editorialists, protecting the reputation of the newspaper and for which they have sufficient backing in the form of evidence about the claims delivered.

3. The second most frequent kind of hedging function in the American political editorials is the writer-oriented category. The most frequent formal realizations of this functional category are non-single lexical hedging means, particularly the strategy of 'attribution to literature'of its two major types -verbaland verbless.Apparently, the American editorialists depend heavily on such impersonal tactics to display objectivity by concealing personal responsibility of the claim they present, thus shielding themselves from any unfavorable reactions if readers find the editorialist's claim unacceptable.

4. The least frequent type of hedging function in the American political editorials is the reader-oriented category. Non-lexical hedging means such as the strategies of 'questions' and 'if clause' are the most frequent formal realizations of this functional category.The American editorialiststend to depend on them to show that they are more concerned about this interpersonal function to addressing the readership, drawing them into negotiation of the unresolved issue to achieve persuasive effects.

5. The study reveals that probably relying on different hedging forms more than others from the side of editorialists for expressing their intentionmay be guided by the expectations on the intended audience. For presenting their claims, the editorialists attempt to do so in accordance with the expectations of their intended readers. They opt for such hedging forms that they think will make the reception of their claims more favorable. 


\section{REFERENCES}

Aijmer, K. (1986). Discourse variation and hedging. In J. Aarts\& W.Meijs (Eds.), Corpus linguistics II: New studies in the analysis and exploitation of computer corpora (pp.1-18).Amsterdam: Rodopi.

Biber, D., Johansson, S., Leech, G., Conrad, S., \&Finegan, E. (1999). Longman grammar of spoken and written English.Harlow: Pearson Education.

Brown, P., \& Levinson, S. C. (1987). Politeness: Some universals in language usage. Cambridge: Cambridge University Press.

Caffi, C. (2007). Mitigation. Amsterdam: Elsevier.

Fraser, B. (1975). Hedged performatives.In P. Cole and J. L. Morgan (Eds.), Syntax and semantics3:Speech acts (pp.187210).New York: Academic Press.

Hinkel, E. (2004).Teaching academic ESL writing: Practical techniques in vocabulary and grammar. Mahwah: Lawrence Erlbaum Associates, Inc.

Holmes, J. (1995).Women, Men, and Politeness. London: Routledge.

Hübler, A. (1983). Understatements and hedges in English. Amsterdam: John Benjamins.

Hyland, K. (1998).Hedging in scientific research articles. Amsterdam: John Benjamins.

Hyland, K. (2005). Prudence, precision, and politeness: Hedges in academic writing .Quaderns de Filologia: EstudisLingüístics, $X$, 99-112.

Kaltenböck, G., Mihatsch,W., \& Schneider,S. (2010). Intoduction. In G. Kaltenböck, W. Mihatsch\& S. Schneider (Eds.), New approaches to hedging (pp.1-13). United Kingdom: Emerald.

Lakoff, G. (1973). Hedges: A study in meaning criteria and the logic of fuzzy concepts. Journal of Philosophical Logic, 2 (4), $458-508$.

Laurinaityte, R. (2011). Hedges in political discourse (Unpublished master's thesis).Pedagogical University Vilnius, Vilnius.

Le, E. (2004). Active participation within written argumentation: metadiscourse and editorialist's authority. Journal of Pragmatics, 36 (4), 687-714. https://doi.org/10.1016/S0378-2166(03)00032-8

Malášková, M. (2014).Hedging in academic discourse: A comparative analysis of applied linguistics and literary criticism research articles (Unpublished doctoral dissertation).Masaryk University, Brno.

Markkanen, R., \&Schröder, H. (1997).Hedging: A challenge for pragmatics and discourse analysis. In R. Markannen\& H. Schröder (Eds.), Hedging \& discourse:Approaches to the analysis of a pragmatic phenomenon in academic texts (pp.3-20). Berlin: Walter de Gruyter. 
Neff-van Aertselaer, J. \&Bunce, C.(2011).The use of small corpora for tracing the development of academic literacies. In F.Meunier, S.De Cock ,G.Gilquin\& M.Paquot(Eds.),A taste for corpora : In honour of Sylviane Granger (pp.6383).Amsterdam:John Benjamins.

Nikula, T. (1997).Interlanguage view on hedging. In R. Markkanen\& H. Schröder (Eds.), Hedging and discourse: Approaches to the analysis of a pragmatic phenomenon in academic texts (pp.188-207). Berlin: Walter de Gruyter.

Prince, E. ,Frader, J. \&Bosk, C. (1980). On hedging in physician- physician discourse. Paper presented at theAAAL Symposium on Applied Linguistics in Medicine, December 29 (pp.1-29). San Antonio,TX.

Salager - Meyer, F. (1994).Hedges and textual communicative function in medical English written discourse.English for Specific Purposes, 13(2), 149-170.

Schröder, H., \& Zimmer, D. (1997).Hedging research in pragmatics: A bibliographical research guide to hedging. In R. Markkanen\& H. Schröder (Eds.), Hedging and discourse: Approaches to the analysis of a pragmatic phenomenonin academic texts (pp. 249-257). Berlin: Walter de Gruyter.

Tahririan, M.H, \&Shahzamani, M. (2009).Hedging in English and Persian editorials: A contrastive study.Iranian Journal of AppliedLinguistics, 12(1), 199-221.

Van Dijk, T. A. (1996).Opinion and ideologies in editorials. Paper presented for the 4th International Symposium of Critical Discourse Analysis, Language, Social Life and Critical Thought, Greece, Athens. Retrieved from:http://www.discursos.org/unpublished\%20articles/Opinions\%20and\%20ideologies\%20in\%20editorials.htm

Varttala, T. (2001).Hedging in scientifically oriented discourse exploring variation according to discipline and intended audience (Unpublished doctoral dissertation). University of Tampere, Finland.

Wales, K. (2011). A dictionary of stylistics (3d ed.). London: Routledge.

Williams, J. (2007). Style: Ten lessons in clariy and grace (9th ed.) New York: Pearson Longman. 